\title{
STUDI PENURUNAN MUKA TANAH (LAND SUBSIDENCE) MENGGUNAKAN METODE PERMANENT SCATTERER INTERFEROMETRIC SYNTHETIC APERTURE RADAR (PS-INSAR) DI KAWASAN KOTA CIMAHI - JAWA BARAT
}

\author{
Yudo Prasetyo*), Sawitri Subiyanto \\ Program Studi Teknik Geodesi, Fakultas Teknik, Universitas Diponegoro, Jl. Prof. Soedarto, SH, Kampus Undip \\ Tembalang, Semarang, Indonesia 50275
}

\begin{abstract}
Abstrak
Proses atau pergerakan penurunan muka tanah telah banyak terjadi di berbagai wilayah di seluruh dunia khususnya kota-kota besar. Dampak dari penurunan muka tanah adalah kerusakan infrastruktur wilayah pemukiman dan gangguan terhadap stabilitas ekonomi dan kehidupan sosial di wilayah tersebut. Oleh sebab itu, kita memerlukan sistem mitigasi bencana alam yang memiliki kemampuan menyajikan analisis kebumian secara cepat dan optimal dalam konsep kajian cepat. Teknologi penginderaan jauh memiliki kemampuan untuk meliput area pengamatan yang luas dalam waktu singkat serta terkait dengan tipikal iklim di Indonesia yang terletak di area tropis (intensitas dan sebaran tutupan awan yang tinggi). Pemilihan teknologi radar adalah salah satu solusi yang baik untuk pemetaan spasial pada estimasi penurunan muka tanah. PS-InSAR adalah metode terbaru dari pemrosesan citra RADAR dimana memberikan akurasi yang baik dan meminimalkan efek dekorelasi. Metode PS-InSAR diterapkan pada wilayah Indonesia merupakan solusi yang tepat karena kemampuannya menembus ketebalan awan dan kabut tebal. Metode ini digunakan dalam analisis penurunan muka tanah pada kota Cimahi-Propinsi Jawa Barat diman hasilnya $17.97 \mathrm{~mm} / \mathrm{yr} \pm 11.5$ mm/yr. Kecamatan Cimahi Utara memiliki kecepatan penurunan muka tanah tertinggi sebesar 22.9 $\mathrm{mm} / \mathrm{yr} \pm 12,7 \mathrm{~mm} / \mathrm{yr}$. Metode ini terbukti sebagai salah satu metode penginderaan jauh yang baik untuk meneliti pergerakan penurunan muka tanah.
\end{abstract}

Kata kunci: DInSAR; Penginderaan Jauh; Penurunan Muka Tanah; PS-InSAR; Radar

\begin{abstract}
[Land Subsidence Study Using Permanent Scatterer Interferometric Synthetic Aperture Radar (PSINSAR) Method in Cimahi City Area-West Java] Process or movement of land subsidence has a lot going on in various regions of the world especially in big cities. The impact of land subsidence can damage urban infrastructure and a disruption to the economic stability and social life in the region. Because of it, we need a natural disaster mitigation system that is able to provide rapid and optimal a geoscience analysis in the concept of quick assessment. A remote sensing technology has the ability to assess large areas in a short time and related with the typical climate of Indonesia that lies in a tropical area (intensity and extensive high cloud cover). Selection of radar technology is one solution that is good for spatial mapping in land subsidence estimation. PS-InSAR is the newest method in RADAR image satellite processing which is give a good accuracy and minimize decorellation effects. PS-InSAR method implementation in Indonesia area is a good solution because this method can penetrate heavy dense clouds and fogs. This method was used in land subsidence analysis at Cimahi City-West Java Province which is result arounds $17.97 \mathrm{~mm} / \mathrm{yr} \pm 11.5 \mathrm{~mm} / \mathrm{yr}$. The South Cimahi District has a highest land subsidence rate arounds $22.9 \mathrm{~mm} / \mathrm{yr} \pm 12,7 \mathrm{~mm} / \mathrm{yr}$. This method has been proven as one of a good remote sensing method to investigate land subsidence movement.
\end{abstract}

Keywords: DInSAR; Land Subsidence; PS-InSAR; Radar; Remote Sensing

\section{Pendahuluan}

Proses atau gerakan turunnya permukaan tanah (land subsidence) telah banyak terjadi di berbagai

\footnotetext{
${ }^{*}$ Penulis Korespondensi.

E-mail: yudo.prasetyo@ft.undip.ac.id
}

wilayah di dunia terutama di kota-kota besar yang berlokasi di kawasan pantai atau dataran aluvial yaitu endapan lepas yang tertranspor ke tempat lain atau tidak berada di sekitar batuan induk yang berukuran butiran berupa pasir dan lempung, seperti: BangkokThailand (Broms, 1992), Osaka-Jepang (Tsukuba, 1998), Tianjin-China (Hu dkk., 2009), Yun-Lin- 
Taiwan (Chu dan Sung, 2004), Hongkong (Liu dkk., 2004), Antartika (Jezek dkk., 1999), Banglades (Rahman, 1995), California-USA (Galloway dkk., 1999), Jawa Timur-Indonesia (Deguchi dkk., 2008), Bandung-Indonesia (Abidin dkk., 2007), Mexico (Allis dkk., 1999), Singapura (Aritoshi dkk., 2006), Kepulauan Aleutian-Salomon (Lu, 2007), Utah-USA (Okubo, 2002) dan Semarang-Indonesia (Marfai, 2003).

Turunnya permukaan tanah yang terakumulasi selama rentang waktu tertentu akan dapat mencapai besaran penurunan hingga beberapa meter lebih (Galloway dkk., 1999) sehingga dampaknya dapat merusak infrastruktur perkotaan yang kemudian dapat saja menjadi gangguan terhadap stabilitas perekonomian dan kehidupan sosial di wilayah tersebut.

Definisi penurunan muka tanah berdasarkan beberapa referensi dapat didefinisikan sebagai berikut: terjadi pada skala regional yaitu meliputi daerah yang luas atau terjadi secara lokal yaitu hanya sebagian kecil permukaan tanah. Hal ini biasanya disebabkan oleh adanya rongga di bawah permukaan tanah, biasanya terjadi di daerah yang berkapur (Whittaker dan Reddish, 1989) atau turunnya kedudukan permukaan tanah yang disebabkan oleh kompaksi tanah (Wei, 2006).

Besaran penurunan muka tanah ditentukan berdasarkan hasil hitungan dan analisis besaran laju penurunan tanah yang bernilai signifikan. Ditinjau dari sudut pandang geodesi, posisi turunnya permukaan tanah ditunjukkan melalui perubahan posisi vertikal muka tanah terhitung dari bidang referensi yang telah ditetapkan sebelumnya. Untuk itu, dibutuhkan suatu teknik pemetaan yang mampu mengamati penurunan muka tanah secara kontinu spasial dan temporal.

Oleh karena itu, diperlukan suatu sistem yang dapat membantu mengukur besaran penurunan muka tanah untuk liputan suatu wilayah yang relatif luas dalam waktu yang cepat sehingga skala prioritas pengelolaan kawasan dapat ditentukan secara efektif dan efisien (Luoto dkk., 2002).

\section{Metode PS-InSAR}

Metode PS-InSAR pertama kali dikemukakan dalam jurnal penelitian berjudul Permanent Scatterers in SAR Interferometry (Ferretti dkk., 1999) pada International Geoscience and Remote Sensing Symposium, 28 Juni-2 Juli 1999 di Hamburg-German.

Penelitian ini memunculkan konsep penelitian single coherent pixels yang kemudian didefinisikan sebagai Permanent Scatterers (PS), menggunakan pasangan citra SAR dalam jumlah besar untuk mendapat akurasi DEM dalam orde sub-sentimeter serta nilai pergerakan permukaan pada area berkoherensi rendah dalam basis piksel per piksel. Teknik PS-InSAR merupakan pengembangan dari teknik konvensional InSAR dan DInSAR. Keuntungan utama dari pengembangan teknik ini adalah untuk mengatasi permasalahan di dalam teknik InSAR dan
DInSAR terkait dengan dekorelasi temporal dan geometrik (Prasetyo, 2014). Prinsip utama dari teknik PS-InSAR memanfaatkan data pengamatan citra SAR multitemporal dalam rentang waktu panjang untuk mendeteksi titik-titik potensial koherensi. Titik-titik PS (Permanent Scatterer) pada umumnya berupa objek-objek solid di permukaan bumi yang menjadi pemantul alami yang relatif koheren terhadap dimensi waktu. Sebaran titik-titik PS dan perbedaan nilai fase untuk setiap individu titik yang dianalisis lebih lanjut menggunakan metode PS-InSAR.

Sehingga secara teknis nilai pergeseran dari titik-titik PS dapat diestimasi melalui korelasi beda fasenya terhadap waktu. Sebagai gambaran dari metode PS-InSAR menggunakan citra radar ERS dapat dilihat secara jelas pada Gambar 1. Untuk model matematika dari perhitungan beda tinggi $(\Delta \mathrm{R})$ beserta gambaran geometri model deformasi per titik pengamatan dapat dilihat pada Gambar 2 dan persamaan (1).

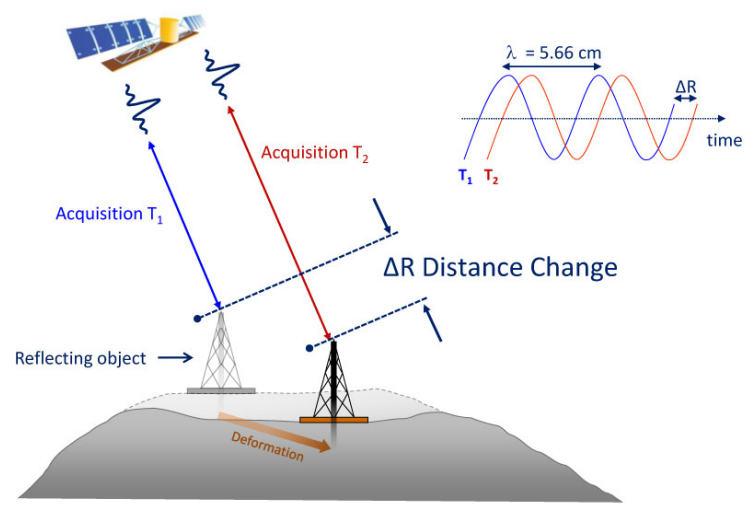

Gambar 1. Geometri Metode PS-InSAR (TRE, 2011)
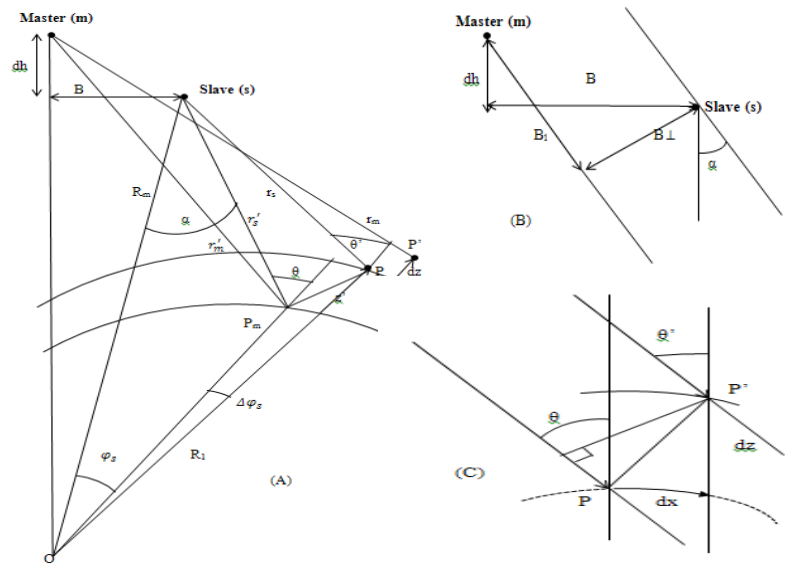

Gambar 2. Geometri Metode PS-InSAR Per Titik Pengamatan (Sumantyo dkk., 2009)

Berdasarkan Gambar 2, persamaan penentuan beda tinggi di dalam teknik pengolahan PS-InSAR berdasarkan model matematika (Sumantyo dkk., 2009), sebagai berikut: 
$d z_{i, j}=\frac{1}{\cos \theta^{\prime}}\left\{\frac{z^{\prime} B_{\perp}}{r_{m} \sin \alpha}+\frac{\lambda \phi}{4 \pi}-B_{d}\right\}$

$d z_{i, j}=\left\{\begin{array}{l}\text { tanda }\left(d z_{i, j}\right)=+(\text { Kenaikan Muka Tanah }) \\ \text { tanda }\left(d z_{i, j}\right)=-(\text { Penurunan Muka Tanah })\end{array}\right.$

Masing-masing besaran dalam persamaan (1), sebagai berikut:

$d z_{i, j}=$ Nilai deformasi pada dua epok pengamatan $\mathrm{i}$ dan $\mathrm{j}$.

$\theta^{\prime}=$ Sudut masuk (incident angle) .

$Z^{\prime}=$ Perbedaan fase yang menunjukkan informasi topografi.

$r_{m}=\operatorname{Jarak}$ (range).

$\phi=$ Sudut masuk pada citra utama dan kedua.

$\alpha=$ Panjang gelombang mikro yang digunakan.

$\mathrm{B}_{\mathrm{d}}=$ Jarak utama (Baseline) mendatar.

$B_{\perp}=$ Jarak utama (Baseline) tegak lurus.

\section{Metode Penelitian}

Pada penelitian ini diterapkan metodologi penelitian yang didesain berdasarkan beberapa aspek, sebagai berikut:

\subsection{Karakteristik Daerah Penelitian}

Daerah penelitian ditetapkan pada kawasan Kota Cimahi dengan batas administrasi yaitu: $6^{\circ} 49^{\prime}-$ $6^{\circ} 53^{\prime}$ LS dan $107^{\circ} 29^{\prime}-107^{\circ} 32^{\prime}$ BT. Kota Cimahi secara administrasi terbagi atas 3 kecamatan dan 15 kelurahan seperti terlihat pada Gambar 3. Pemilihan daerah ini sebagai area penelitian didasarkan atas tingkat kepadatan penduduk (14 ribu jiwa per km persegi) dan perkembangan pusat-pusat industri serta militer. Sehingga dampak dari penurunan muka tanah akan sangat berpengaruh terhadap kehidupan sosial dan ekonomi secara umum.

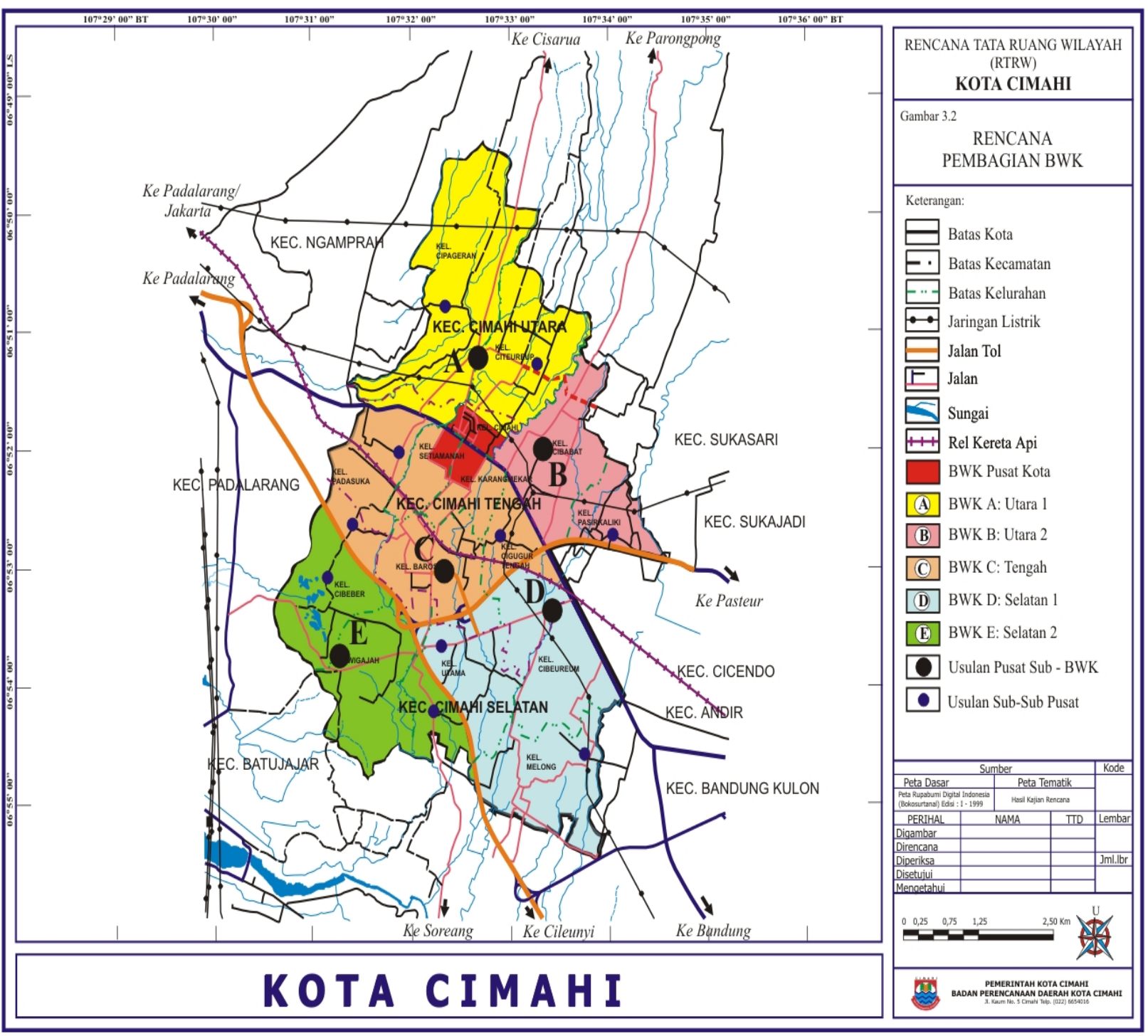

Gambar 3. Peta Administrasi Kota Cimahi (Bappeda Cimahi, 2014) 


\subsection{Data Penelitian}

Data utama yang digunakan dalam penelitian ini dapat diambil dari 19 citra SAR ALOS PALSAR tingkatan data 1.0 dan 1.1 (dibawah lisensi CERES Lab-Chiba University dan InSIG Lab-Institut Teknologi Bandung), ditampilkan di Tabel 1.

\subsection{Metodologi Penelitian}

Metode penelitian ini didasarkan atas beberapa tahapan pengolahan yang dapat dilihat secara rinci pada Gambar 4.

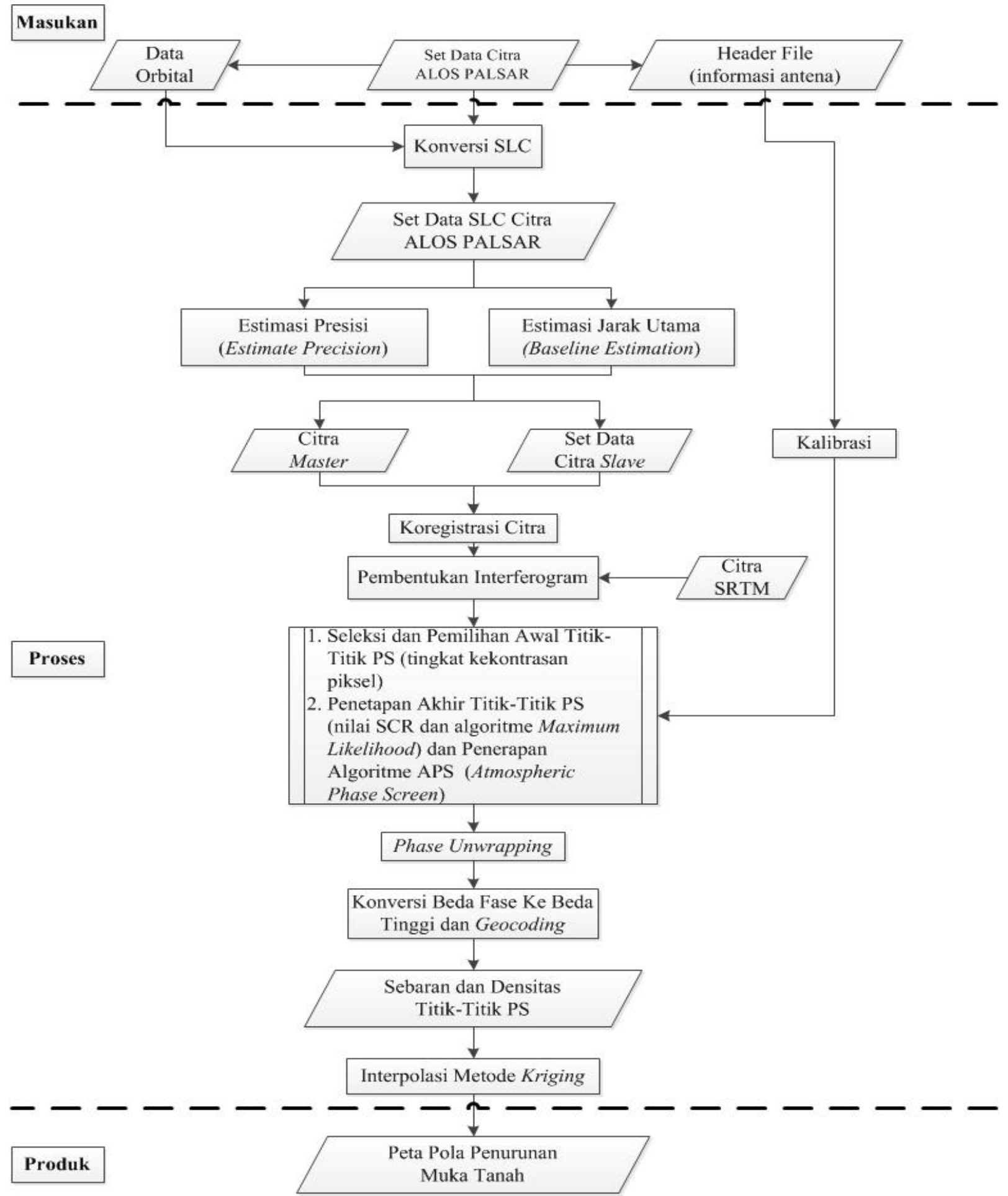

Gambar 4. Diagram Alir Penelitian Berdasarkan Metode PS-InSAR 


\section{Teknik, 35 (2), 2014, 78-85}

Tabel 1. Penggunaan data ALOS PALSAR dalam penelitian

\begin{tabular}{|c|c|c|c|c|}
\hline No. & Kode ALOS & Format & Level & Tanggal Akuisisi \\
\hline 1. & ALPSRP086653760 & FBS & 1.0 & $10-09-2007$ \\
\hline 2. & ALPSRP106783760 & FBS & 1.0 & $26-01-2008$ \\
\hline 3. & ALPSRP133623760 & FBS & 1.0 & $28-07-2008$ \\
\hline 4. & ALPSRP153753760 & FBS & 1.0 & $13-12-2008$ \\
\hline 5. & ALPSRP160463760 & FBS & 1.0 & $28-01-2009$ \\
\hline 6. & ALPSRP187303760 & FBS & 1.0 & $31-07-2009$ \\
\hline 7. & ALPSRP207433760 & FBS & 1.0 & $16-12-2009$ \\
\hline 8. & ALPSRP254403760 & FBS & 1.0 & $03-11-2010$ \\
\hline 9. & ALPSRP078707040 & FBD & 1.1 & $17-07-2007$ \\
\hline 10. & ALPSRP085417040 & FBD & 1.1 & $01-09-2007$ \\
\hline 11. & ALPSRP125677040 & FBD & 1.1 & $03-06-2008$ \\
\hline 12. & ALPSRP132387040 & FBD & 1.1 & $19-07-2008$ \\
\hline 13. & ALPSRP186067040 & FBD & 1.1 & $22-07-2009$ \\
\hline 14. & ALPSRP199487040 & FBD & 1.1 & $22-10-2009$ \\
\hline 15. & ALPSRP246457040 & FBD & 1.1 & $09-09-2010$ \\
\hline 16. & ALPSRP248937040 & FBD & 1.1 & $26-09-2010$ \\
\hline 17. & ALPSRP255647040 & FBD & 1.1 & $11-11-2010$ \\
\hline 18. & ALPSRP259877040 & FBD & 1.1 & $10-12-2010$ \\
\hline 19. & ALPSRP269067040 & FBD & 1.1 & $11-02-2011$ \\
\hline
\end{tabular}

\subsection{Asumsi Penelitian}

Asumsi yang digunakan dalam penelitian (Prasetyo, 2014), sebagai berikut:

1. Fase residu (residual phase) yang bernilai kurang dari satu periodik fase dari hasil proses penapisan (atmospheric phase screen) terhadap sinyal atmosferik dianggap tidak terlalu signifikan (tahapan pengolahan LPS-InSAR).

2. Seluruh data pengamatan (citra SAR) dianggap memiliki bobot ketelitian yang sama berdasarkan metode estimator koherensi, tipe sensor radar, akurasi citra SAR dan metode koregistrasi.

\section{Hasil dan Pembahasan}

Hasil pengolahan set 19 data citra radar ALOS PALSAR di wilayah Kota Cimahi menggunakan metode PS-InSAR dapat dilihat pada Tabel 2 dan Gambar 5 dan 6.

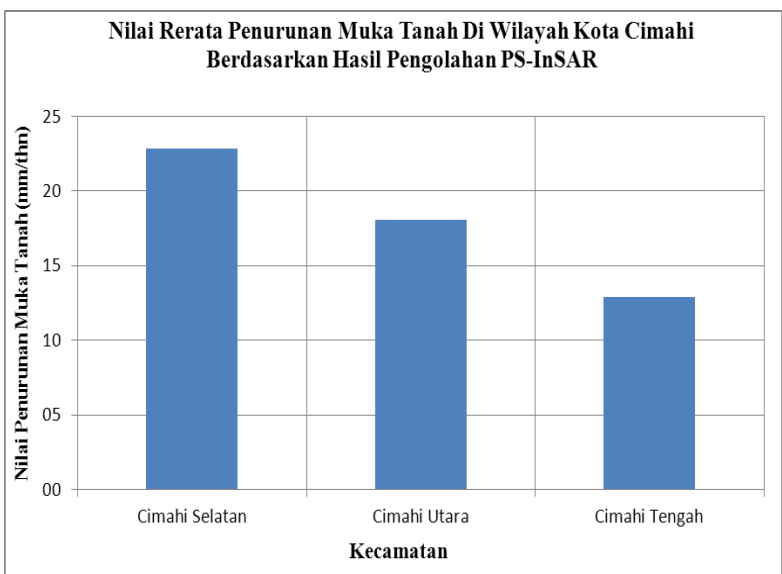

Gambar 5. Nilai rerata penurunan muka tanah di wilayah Kota Cimahi berdasarkan hasil pengolahan PS-InSAR untuk set 19 data citra ALOS PALSAR
Berdasarkan hasil pengolahan data radar menggunakan metode PS-InSAR didapatkan hasil bahwa Kecamatan Cimahi Selatan memiliki tingkat penurunan muka tanah rerata lebih tinggi dibandingkan wilayah kecamatan lainnya (Cimahi Utara dan Tengah) sebesar 22,9 mm/thn. Hal ini menunjukkan bahwa resiko dampak penurunan muka tanah di wilayah Kecamatan Cimahi Selatan lebih tinggi. Hal ini didukung oleh padatnya tingkat hunian penduduk di kawasan tersebut.

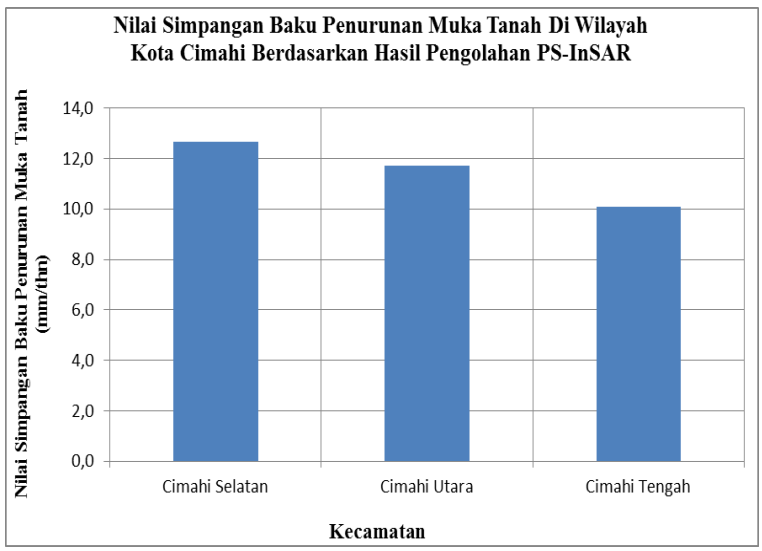

Gambar 6. Nilai simpangan baku penurunan muka tanah di wilayah Kota Cimahi berdasarkan hasil pengolahan PS-InSAR untuk set 19 data citra ALOS PALSAR

Untuk tingkat ketelitian dari hasil pengolahan data diperoleh bahwa nilai simpangan baku terkecil didapatkan pada kawasan Kecamatan Cimahi Tengah sebesar $10,1 \mathrm{~mm} / \mathrm{thn}$. Hal ini mengindikasikan bahwa nilai penurunan muka tanah sebesar $12,9 \mathrm{~mm} / \mathrm{thn}$ di Kecamatan Cimahi Tengah memiliki tingkat kepercayaan yang lebih baik dibandingkan hasil pengukuran penurunan muka tanah di wilayah kecamatan lainnya.

Sebagai gambaran umum terkait sebaran spasial penurunan muka tanah dapat dilihat pada Gambar 7. Berdasarkan Gambar 7 dapat diperoleh gambaran sebaran intensitas penurunan muka tanah yang cukup tinggi (ditunjukkan oleh warna merah) dan yang rendah (ditunjukkan oleh warna biru). 
Tabel 2. Hasil pengolahan PS-InSAR untuk set 19 data citra ALOS PALSAR di wilayah Kota Cimahi

\begin{tabular}{|c|l|c|c|c|c|c|c|c|}
\hline No. & Nama Kecamatan & Titik PS & $\begin{array}{c}\text { Rentang Deformasi } \\
(\mathbf{m m} / \mathrm{thn})\end{array}$ & $\begin{array}{c}\text { Rentang Penurunan Muka } \\
\text { Tanah }(\mathbf{m m} / \mathrm{thn})\end{array}$ & $\begin{array}{c}\text { Penurunan Muka Tanah } \\
\text { Minimum }(\mathbf{m m} / \mathrm{thn})\end{array}$ & $\begin{array}{c}\text { Penurunan Muka Tanah } \\
\text { Maksimum(mm/thn) }\end{array}$ & $\begin{array}{c}\text { Nilai Rerata Penurunan } \\
\text { Muka Tanah (mm/thn) }\end{array}$ & $\begin{array}{c}\text { Simpangan Baku Penurunan } \\
\text { Muka Tanah (mm/thn) }\end{array}$ \\
\hline 1 & Cimahi Selatan & 19930 & 110.8 & 55.7 & 0.002 & 55.7 & 22.9 & 12.7 \\
\hline 2 & Cimahi Utara & 18328 & 113.1 & 54.6 & 0.013 & 54.6 & 18.1 & 11.7 \\
\hline 3 & Cimahi Tengah & 15376 & 116.6 & 58.8 & 0.002 & 58.8 & 12.9 & 10.1 \\
\hline
\end{tabular}

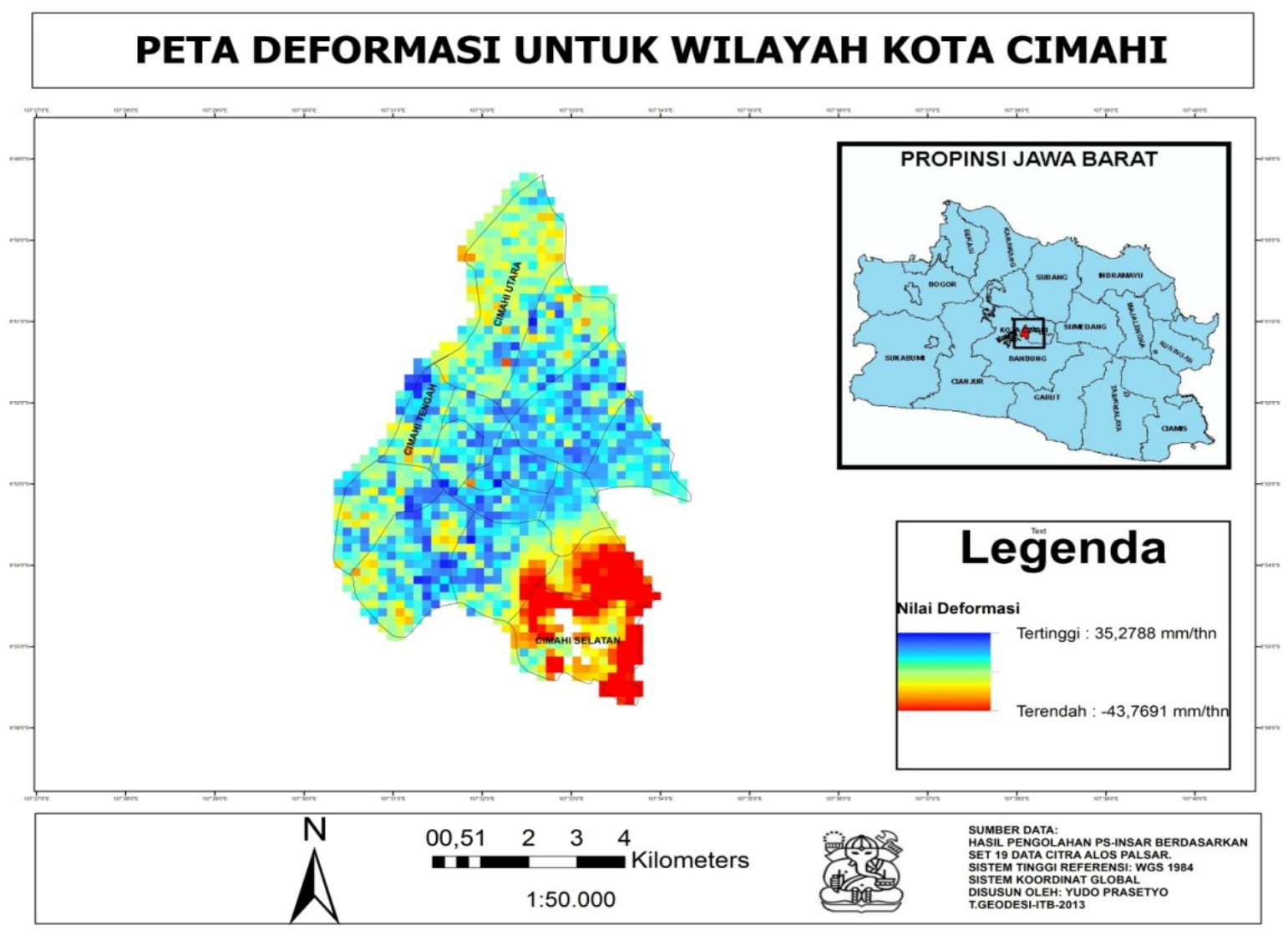

Gambar 7. Peta deformasi untuk wilayah Kota Cimahi hasil pengolahan set 19 data citra ALOS PALSAR menggunakan metode PS-InSAR 


\section{Kesimpulan dan Saran}

Berdasarkan hasil pengolahan data, maka dapat ditarik kesimpulan sebagai berikut:

1. Berdasarkan hasil pengolahan data radar menggunakan metode PS-InSAR didapatkan hasil bahwa Kecamatan Cimahi Selatan memiliki tingkat penurunan muka tanah rerata lebih tinggi dibandingkan wilayah kecamatan lainnya (Cimahi Utara dan Tengah) sebesar 22,9 mm/thn.

2. Untuk tingkat ketelitian dari hasil pengolahan data diperoleh bahwa nilai simpangan baku terkecil didapatkan pada kawasan Kecamatan Cimahi Tengah sebesar $10,1 \mathrm{~mm} / \mathrm{thn}$. Hal ini mengindikasikan bahwa nilai penurunan muka tanah sebesar 12,9 mm/thn di Kecamatan Cimahi Tengah memiliki tingkat kepercayaan yang lebih baik dibandingkan hasil pengukuran penurunan muka tanah di wilayah kecamatan lainnya.

3. Tingkat penurunan muka tanah yang tinggi di Kecamatan Cimahi Selatan didukung oleh tingginya tingkat hunian penduduk serta perkembangan industri. Hal ini memicu tingginya kebutuhan air bawah tanah yang menjadi salah satu penyebab terjadi penurunan muka tanah di kawasan Kota Cimahi - Jawa Barat.

4. Penggunaan metode PS-InSAR mampu memberikan informasi deformasi secara cepat dan tepat, serta mampu mengatasi kendala awan yang umumnya terjadi di kawasan tropis dan meminimalkan biaya pengukuran deformasi.

Atas dasar hasil penelitian yang diperoleh maka perlu dilakukan beberapa hal untuk peningkatan kualitas penelitian di masa mendatang, sebagai berikut:

1. Perlu dilakukan tahapan validasi data pengukuran penurunan muka tanah menggunakan metode kebumian lainnya seperti penerapan metode Global Positioning System (GPS).

2. Penggunaan metode PS-InSAR masih membutuhkan jumlah data radar dalam ukuran besar serta perangkat keras berspesifikasi tinggi. Sehingga perlu dilakukan proses optimalisasi metode PS-InSAR di dalam pemrosesan data.

3. Masih minimnya sumber daya manusia di Indonesia yang mampu melakukan pengolahan data radar secara baik dan benar. Hal ini menyulitkan penerapan metode PS-InSAR secara umum di negara Indonesia.

\section{Ucapan Terima Kasih}

Penulis mengucapkan terima kasih atas bantuan pengadaan citra satelit ALOS PALSAR kepada Prof. DR. Joshaphat Tetuko Sri Sumantyo selaku Kepala Laboratorium JMRSL-CERES Universitas Chiba Jepang dan Prof. DR. Ketut Wikantika selaku Kepala Center of Remote Sensing (CRS) Institut Teknologi Bandung Indonesia. Serta Fakultas Teknik yang telah memberikan fasilitas dan dukungan kepada penelitian di laboratorium penginderaan jauh dan fotogrammetri Program Studi Teknik Geodesi - Universitas Diponegoro.

\section{Daftar Pustaka}

Abidin, H.Z., Andreas, H., Gamal, M., dan Darmawan, D. (2006). Land Subsidence Characteristic Of Bandung Basin (Indonesia) Between 2000 and 2005 as Estimated from GPS Survey. XXIII FIG Congress, Munich, p.1-14.

Broms, B. (1992). Ground Settlements in Singapore. Geomechanics and Water Engineering in Environmental Management, Rotterdam, p.117-128.

Chu, I., dan Sung, G. (2004). Land Subsidence Prevention in Taiwan. http://www.water.tku. edu.tw/wwf3/news/paper/Groundwater-121(0310).pdf. Di download pada tanggal 18 Oktober 2009.

Deguchi, T., Maruyama, Y., Kato, M., dan Kobayashi, C. (2008). Surface Displacement Around Mud Vulcano, East Java Captured by Insar using Palsar Data. Earth Remote Sensing Data Analysis Center (ERSDAC), Tokyo, 1-6.

Ferretti, A., Prati, C., dan Rocca, F. (1999). Permanent Scatterers in SAR Interferometry. International Geoscience and Remote Sensing, Hamburg, 1528-1530.

Galloway, D., Jones, D.R., dan Ingebritsen, S.E. (1999). Land Subsidence in The United States. US Geological Survey, New York, 1182, 1-15.

Hu, B., Zou, J., Wong, J., Chen, Z.L., Wang, D., dan $\mathrm{Xu}$, S. (2009). Risk assessment of land subsidence at Tianjin coastal area in China. Springer Berlin: Heidelberg, p.1-14.

Jezek, K.C., Liu, H., Zhao, Z., dan Li, B. (1999). Improving A Digital Elevation Model of Antarctica Using Radar Remote Sensing Data and GIS Techniques. Ohio: V.H. Winston\&Son Inc, p.457-470.

Lu, G. (2007). InSAR Imaging of Volcanic Deformation Over Cloud-prone AreasAleutian Islands. Photogrammetric Engineering \& Remote Sensing, New York, p.1-12.

Luoto, M., Kuusaari, M., dan Toivonen, T. (2002). Modelling Butterfly Distribution Based on Remote Sensing Data. Finnish Environment Institute, Turku, p.443-458.

Marfai, R. (2003). GIS Modelling of River and Tidal Flood Hazards In A Waterfront City (Case Study: Semarang City, Central Java, Indonesia). ITC, The Netherlands, p.1-123.

Prasetyo, Y. (2014). Analisis Optimisasi dan Estimasi Penentuan Penurunan Muka Tanah Menggunakan Teknik Light Permanent Scatterer Interferometric Synthetic Aperture Radar (LPS-InSAR) (Studi Kasus: Cekungan Bandung). PhD Dissertation, ITB, Bandung. 
Teknik, 35 (2), 2014, 85

Rahman, M. H. (1995). Influence of Geostructural Aspects In Land Subsidence. The Fifth International Symposium on Land Subsidence, The Hague, p.422-431.

Sumantyo, J.T.S., M. Shimada, P.P. Mathieu, dan H.Z. Abidin. (2009). Long Term Continuously DInSAR for Volume Change Estimation of Land Deformation. IEEE Transactions on Geoscience and Remote Sensing, New York, p.1-11.
Wei, L. (2006). Land Subsidence And Water Management In Shanghai. Master Thesis. TU Delft, The Netherlands, p.1-79.

Whitaker, B.N. dan Reddish. (1989). Subsidence Occurrence, Prediction, and Control. Elsevier Science Publishing Company INC, Netherland. 